\title{
ATIVISMO JUDICIAL: PANORAMA ATUAL NO SUPREMO TRIBUNAL FEDERAL
}

\begin{abstract}
Arthur Maximus Monteiro
Mestre em Direitos Fundamentais pela Universidade de Lisboa. Pós-graduado em Direito Processual Civil pela Universidade Estadual do Ceará/FESAC. Advogado. arthur.maximus@hotmail.com
\end{abstract}

SUMÁRIO: Introdução. 1. Ativismo judicial no Supremo Tribunal Federal. Conclusão. Referências.

Resumo: $\mathrm{O}$ ativismo judicial tem se apresentado, cada vez mais, como tendência do sistema judicial brasileiro. A invasão das esferas de competência do Poder Legislativo pelo Poder Judiciário encontrou terreno fértil no Supremo Tribunal Federal. No presente artigo, analisaremos como o ativismo passou a dominar a agenda da Suprema Corte Brasileira, assim como suas implicações para o panorama jurídico-constitucional do país.

Palavras-chave: Direito Constitucional. Ativismo judicial. Neoconstitucionalismo.

\section{INTRODUÇÃO}

$\mathrm{O}$ ativismo judicial tem se mostrado uma tendência dominante no Judiciário brasileiro nos últimos anos. Embora, pela estrutura definida pelo constituinte de 1988, ao Poder Judiciário não tivessem sido atribuídas maiores competências legislativas, a verdade é que nos últimos anos tem-se assistido a um processo de deslocamento cada vez maior das resoluções políticas dos centros naturais de decisão - Executivo e Legislativo - para o Poder Judiciário. Trata-se daquilo que parte da mídia e da doutrina convencionou chamar de "judicialização da política" (VIANA, 1999, p. 22).

Mesmo com a ampliação dos poderes por parte do constituinte de 1988, parcelas relevantes da doutrina e da jurisprudência pareciam um tanto inconformadas com o desenho proposto para o Poder Judiciário (BARCELLOS, 2008, p. 52). A seu ver, a Carta Fundamental teria deixado margem mínima de manobra para os juízes na resolução de conflitos (BARROSO, 2008 , p. 12), especialmente aqueles fomentados por vazios normativos, decorrentes de direitos fundamentais pendentes de concretização por parte do legislador (MORAIS, 2009, p. 77-78).

De certa forma, depois da Constituição de 1988, era esperado que o Judiciário transformasse-se em estuário de todas as decepções de uma população acostumada a uma classe política pouco afeita à sua tarefa de trazer bem-estar para o povo que governa (AGRA, 2009, p. 1365). Dentro dessa crise do sistema representativo, o Supremo Tribunal Federal encontrou a perfeita janela de 
oportunidade para substituir-se aos representantes eleitos pelo povo como instância política responsável pela efetivação de direitos constitucionais carentes de regulamentação (CUNHA JR., 2008, p. 43). Não se contava, contudo, que o órgão de cúpula do Poder Judiciário brasileiro arrogasse para si a competência para ditar as políticas públicas e até mesmo definir os rumos do país.

\section{Ativismo Judicial no Supremo Tribunal Federal}

Na parte que lhe toca, o Supremo Tribunal Federal assumiu a dianteira do movimento ativista judicial brasileiro. Fê-lo com o propósito explícito de expandir seus poderes e, por conseguinte, provocar quase um reordenamento institucional no país. E, por mais estranho que pareça, houve um método nesse processo. Trata-se de uma peça encenada em três atos.

\subsection{0 conhecimento de ações "inconhecíveis"}

Ela começa, primeiramente, com o abandono às normas processuais constitucionais relativas ao conhecimento de ações diretas. Para dar início a esse processo, o Supremo Tribunal Federal começou a "pinçar" processos de grande repercussão na opinião pública. Casos em que ou o desinteresse dos governantes ou o embate político impediam que se chegasse à solução desejada pela maior parte da sociedade por intermédio da via legislativa. Dessa forma, ações, por assim dizer, "inconhecíveis" foram conhecidas em favor da supostamente maior "segurança jurídica" derivada das decisões prolatadas em sede de controle abstrato (MENDES, 2012, p. 671). Nesse caso, os instrumentos de ação do STF foram, principalmente, a Adin e a ADC.

Mesmo contra normas processuais expressas ${ }^{1}$, o STF passou a julgar o mérito das demandas, em vez de simplesmente as extinguir. Agiu dessa maneira confiante de que, respaldado por uma população insatisfeita com a classe política, nenhum outro poder haveria de confrontar suas decisões. Sem receios, caminhou rumo ao desconhecido.

O primeiro passo dessa nova "tendência" da jurisdição constitucional brasileira talvez tenha sido o julgamento da constitucionalidade da regra "antinepotismo", criada pelo Conselho Nacional de Justiça (FALCONE, 2008, p. 214-215).

Desde sempre, a população assistia revoltada ao festival de nomeações de apaniguados desqualificados para cargos de livre nomeação e exoneração nos tribunais de todo o país. Tudo porque determinada pessoa possuía algum vínculo de parentesco com juiz, desembargador ou ministro de tribunal superior. À falta de norma que impedisse a prática, reclamar era tudo que o cidadão poderia fazer.

Não foi o que pensou o Conselho Nacional de Justiça (CNJ). Criado pela Emenda Constitucional $n^{\circ} 45 / 2004$, o CNJ determinou que todos os parentes de juízes, desembargadores e ministros ocupantes de cargos em comissão deveriam ser exonerados (FALCONE, 2008, p. 214).

Contudo, pelos próprios termos da Emenda Constitucional que o criou, o Conselho somente poderia produzir atos regulamentares, não atos normativos primários (SILVA, 2009, p. 564). Para escapar a essa limitação, o CNJ resolveu proibir o nepotismo a pretexto de "interpretar" o caput do art. 37 da $\mathrm{CF} / 88^{2}$, que dispõe sobre os princípios regentes da Administração Pública em geral, dentre eles os princípios da moralidade e da impessoalidade (FALCONE, 2008, p. 21).

1 Cf. Leis nos 9.868/99 e 9.882/99.

2 “Art. 37. A administração pública direta e indireta de qualquer dos Poderes da União, dos Estados, do Distrito Federal e dos Municípios obedecerá aos princípios de legalidade, impessoalidade, moralidade, publicidade e eficiência e, também, ao seguinte:". 
Muitas ações individuais foram ajuizadas questionando tal resolução. O fundamento dessas demandas era eminentemente formal: o CNJ, mesmo movido por nobres sentimentos, exacerbara sua competência, invadindo esfera restrita ao legislador. Argumentava-se que a Resolução $n^{\circ}$ 07/2005 não teria limitado-se a interpretar a norma constitucional; produzira de fato outra norma, inteiramente nova, a regulamentar o acesso a cargos de livre nomeação e exoneração no Poder Judiciário (FALCONE, 2008, p. 214).

Os argumentos eram perfeitamente válidos, e muitas medidas liminares foram deferidas em favor dos parentes de juízes, desembargadores e ministros que já ocupavam cargos em comissão. A constitucionalidade da resolução, portanto, fora colocada em xeque.

Para evitar a multiplicação de processos e a ineficácia da resolução, a Associação dos Magistrados do Brasil (AMB) ingressou com Ação Declaratória de Constitucionalidade da Resolução n ${ }^{\circ}$ 07/2005 do CNJ (ADC n 12/DF) .

Havia, no entanto, uma questão processual a superar. A ADC somente é cabível quando exista "lei ou ato normativo federal" a ser atacado (SILVA, 2008, p. 56-67). Parece claro, portanto, que somente normas dotadas de caráter geral e abstrato, produzidas por entes legislativos, podem ser objeto da ação declaratória de constitucionalidade (BASTOS, 2010, p. 584).

Como sustentou o Ministro Marco Aurélio na sessão de julgamento dessa ADC, só havia duas alternativas: ou o $\mathrm{CNJ}$ exacerbara sua competência constitucional, editando norma de caráter geral e abstrato, e, nesse caso, o pedido deveria ser julgado improcedente - resultando na declaração de inconstitucionalidade da Resolução ${ }^{4}$; ou o CNJ de fato limitara-se a interpretar a norma constitucional, e, sendo ato regulamentar, destituído de caráter geral e abstrato, não se poderia conhecer da ADC.

Nenhuma das duas hipóteses vingou. O STF, vencido o Ministro Marco Aurélio, conheceu da ADC e julgou-a procedente (RAMOS, 2010, p. 256-264).

Com esse caso, abriu-se o “precedente”. Algum tempo depois, o Supremo Tribunal Federal deu um passo adiante.

Há muito tempo a população censurava a infame prática de parlamentares mudarem de partido logo após a eleição, nem sempre movidos por interesses, por assim dizer, "republicanos". Embora houvesse várias propostas visando a limitar ou mesmo extirpar a prática, nenhuma delas chegou a avançar no Congresso Nacional (FALCONE, 2008, p. 199-203).

3 Cf. ADC n ${ }^{\circ}$ 12, Relator Ministro Ayres Britto, julgado em 20.8.08, publicada no DJU de 12.9.08.

4 Decorrente da natureza dúplice das decisões prolatadas em controle abstrato. Por natureza dúplice entenda-se: as decisões proferidas em sede de controle abstrato de normas, embora contenham um determinado pedido, podem resultar em seu contrário. Mesmo que tal medida cause espanto a parte da doutrina (MIRANDA, 2008, p. 81), se um dos legitimados ingressa com um dos três instrumentos processuais acima referidos pedindo, por exemplo, a declaração de inconstitucionalidade de norma, e, ao final, julga-se improcedente o pedido, o resultado será a declaração de constitucionalidade do dispositivo. Do mesmo modo, pedida a declaração de constitucionalidade de determinada norma e sendo, ao final, julgado improcedente o pedido, o resultado será a sua declaração de inconstitucionalidade. E aqui o sistema brasileiro afasta-se radicalmente, por exemplo, do sistema português. Neste, o julgamento de improcedência da declaração de inconstitucionalidade resulta tão só nisto: não se declara a inconstitucionalidade da norma; a decisão conduz a uma coisa julgada meramente formal. (MIRANDA, 2008, p. 71). No caso brasileiro, não. A decisão de improcedência produz coisa julgada material, com os mesmos efeitos de uma decisão de procedência da ação. A rigor, a natureza dúplice das decisões não é estranha ao nosso sistema processual. No processo civil de há muito aceita-se que uma ação proposta por um autor em face de um réu venha a resultar, por exemplo, na condenação do autor em favor do réu. É o que acontece, por exemplo, nos procedimentos especiais, como as ações possessórias (reintegração e manutenção de posse, e interdito proibitório) e as ações de consignação em pagamento e prestação de contas (MARCATO, 2006, p. 61-62). 
À falta de norma legal, o Tribunal Superior Eleitoral (TSE) decidiu editar as Resoluções $n^{\text {os }} 22.610 / 2007$ e 22.733/2008. Por tais resoluções, estabelecera-se que o mandato legislativo pertence ao partido, não à pessoa do candidato eleito. Portanto, se este, injustificadamente, mudasse de partido, perderia o mandato. Para o seu lugar, iria outro nome indicado pelo partido ao qual pertencia (FALCONE, 2008, p. 199-203).

O fundamento normativo dessas resoluções, segundo o TSE, era o Código Eleitoral. Ao estabelecer a ordem de numeração dos candidatos - primeiro, o número do partido, depois, o do candidato - e ao fato de que, para concorrer a qualquer cargo eletivo, o cidadão deve necessariamente filiar-se a uma agremiação partidária, "implicitamente" o Código Eleitoral estava a dizer que o mandato pertenceria antes ao partido do que ao próprio parlamentar (FALCONE, 2008, p. 201).

Ajuizou-se uma $\operatorname{Adin}\left(n^{\circ} 4.086 / D F\right)^{5}$ questionando-se ambas as resoluções. A rigor, não seria necessário grande esforço para concluir que o TSE criara nova hipótese de perda de condição de elegibilidade, "indo muito além da força prescritiva do princípio da representação partidária proporcional” (RAMOS, 2010, p. 254) ${ }^{6}$.

Mais uma vez o Ministro Marco Aurélio, agora ladeado pelo Ministro Eros Grau, advertiu o Tribunal para a restrição de possibilidades de julgamento: ou o TSE apenas interpretara o Código Eleitoral e, nesse caso, não caberia Adin; ou o TSE produzira uma norma exacerbando sua competência estrita, e o resultado deveria ser a declaração de inconstitucionalidade da resolução ${ }^{7}$.

Nem uma coisa nem outra. O STF conheceu da Adin e julgou-a improcedente. Como asseverou o Ministro Gilmar Mendes, "temos [o STF] avançado na cognoscibilidade também de questões que antes não eram admissíveis em sede de ADI". Fazendo questão de registrar o precedente anterior, o Ministro Gilmar Mendes deixou claro que não se tratava sequer "de um passo novo", mas tão somente da "consolidação de um entendimento" .

Portanto, pouco importava saber se à primeira decisão faltaram elementos mínimos a lhe sustentar juridicamente. Importava, apenas, saber que houvera decisão idêntica em caso semelhante, a "amparar" o novo posicionamento9. Ao fim e ao cabo, ambas as resoluções do TSE foram declaradas constitucionais, com efeito vinculante e eficácia erga omnes.

E, ao contrário do que dissera o Ministro Gilmar Mendes, houvera, sim, "um passo novo". No item 5 do acórdão - prenúncio do que viria mais adiante - afirmou-se que a constitucionalidade das resoluções justificava-se por seu "caráter excepcional e transitório, tão somente como mecanismos para salvaguardar a observância da fidelidade partidária enquanto o Poder Legislativo, órgão legitimado para resolver as tensões típicas da matéria, não se pronunciar".

Se por um lado o STF reconhecera no Legislativo a competência exclusiva para regulamentar a matéria, por outro admitira, ainda que implicitamente, a possibilidade de o Poder Judiciário fazê-lo, desde que em situações "de caráter excepcional e transitório".

5 Cf. Adin n ${ }^{\circ}$ 4.086, Relator Ministro Joaquim Barbosa, julgado em 12.11.08, publicada no DJU de 20.11.08.

6 O resultado do caso e sua "construção teórica" é fortemente criticado por Elival da Silva Ramos (RAMOS, 2010, p. 245-256). Para uma ótica portuguesa sobre o ativismo judicial no caso do Tribunal Superior Eleitoral, conferir o trabalho de Maria Benedita Urbano (URBANO, 2010, p. 413-416).

7 Cf. voto do Ministro Marco Aurélio na Adin n ${ }^{\circ} 4.086 / \mathrm{DF}$.

8 Trecho do voto do Ministro Gilmar Mendes na Adin $n^{\circ}$ 4.086/DF.

9 O que, por si só, é juridicamente discutível. Não há, no Brasil, um sistema de fiscalização de constitucionalidade tipicamente norte-americano, em que o efeito da decisão proferida anteriormente respalda, de per se, a decisão futura, tal qual faria uma norma legislativa. No caso brasileiro, a atividade jurisdicional baseia-se, fundamentalmente, na subsunção de um fato a uma norma stricto sensu e não de um fato a uma decisão judicial anterior. Eis o erro palmar cometido pelos adeptos do novo "reposicionamento institucional" do Supremo Tribunal Federal (MORAIS, 2011, p. 149). 
Assim, do conhecimento de ações "inconhecíveis", chegou-se rapidamente à possibilidade de o STF legislar, ainda que "excepcional e transitoriamente".

Mas isso ainda parecia pouco.

\subsection{A "abstratização" do controle concreto}

Livrando-se das amarras da "velha dogmática jurídica", aparentemente superadas pela aceitação geral das duas anteriores incursões furtivas no terreno legislativo, a jurisdição constitucional brasileira apertou o passo de sua nouvelle vague. Para isso, produziu a chamada "abstratização" do controle concreto de constitucionalidade.

Conforme assinalado alhures, o controle concreto de constitucionalidade pelo STF dá-se principalmente pela via incidental do recurso extraordinário. Nesse caso, a sentença tem ou deveria ter - efeitos meramente inter partes, sem que a decisão possa ser estendida a pessoas que não integraram o processo. Todavia, o STF tem buscado "alargar" os efeitos das decisões proferidas no controle concreto de constitucionalidade.

Sabe-se que o recurso extraordinário, como meio concreto e incidental de controle de constitucionalidade, vincula apenas as partes do processo. Os efeitos da decisão não extrapolam os limites da lide, como ocorre no controle abstrato, no qual a decisão do STF possui eficácia vinculante e erga omnes (BASTOS, 2010, p. 584).

Há, porém, uma ressalva importante a fazer. A própria Constituição autoriza o Supremo a notificar o Senado Federal da declaração de inconstitucionalidade de determinada lei ou ato normativo, e o Senado, querendo, pode "suspender a execução, no todo ou em parte, de lei declarada inconstitucional por decisão definitiva do Supremo Tribunal Federal” (SILVA, 2009 , p. 415) ${ }^{10}$.

Assim, poderá o Senado Federal, em juízo eminentemente discricionário, conferir efeitos erga omnes a uma decisão prolatada pelo STF em controle concreto (MORAIS, 2011, p. 792-793). Como assevera Lênio Streck, "as decisões exsurgentes do controle difuso não possuem autonomia, pois dependem do 'socorro' do poder legislativo para adquirir força vinculante erga omnes” (STRECK, 2010, p. 7). Desde a CF/88, esse é o entendimento majoritário (VELLOSO, 1991, P. 178).

Não há dúvida, porém, de que essa "extensão" de efeitos operada pelo Senado possui efeitos apenas ex nunc (SILVA, 2009, p. 415). Daí a razão pela qual o dispositivo constitucional fala em "suspender a execução" da lei declarada inconstitucional, e não "declarar a nulidade" da referida norma, tarefa que compete à jurisdição constitucional (STRECK, 2010, p. 7).

Há, todavia, quem defenda que, embora o sistema brasileiro tenha mantido a coexistência dos sistemas abstrato e concreto, não haveria qualquer distinção ontológica entre ambos. Para essa corrente, mesmo sendo certo que no controle abstrato a inquirição de constitucionalidade constitui questão principal da lide, e, no controle concreto, a matéria constitucional é meramente prejudicial, as decisões proferidas pelo Supremo Tribunal Federal em um e em outro processo seriam rigorosamente as mesmas (TAVARES, 2001, p. 285).

Foi o que insinuou o STF no julgamento da Reclamação n ${ }^{0} 4.335 / \mathrm{AC}^{11}$.

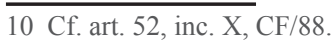

11 A reclamação é um instrumento processual de acesso direto à Suprema Corte, que busca "a preservação da competência do STF" e a "garantia da autoridade de suas decisões" (BASTOS, 2010, p. 571). 
Nesse caso, ajuizara-se uma reclamação diretamente no Supremo Tribunal Federal. Alegava-se que certo juiz do estado do Acre estaria a descumprir a decisão proferida pelo STF no julgamento do Habeas Corpus (HC) n ${ }^{\circ} 82.959$, o qual julgara inconstitucional a impossibilidade de progressão de regime prisional nos crimes ditos "hediondos".

Tratava-se, a princípio, de caso manifesto de indeferimento liminar da reclamação. Como o "atalho" processual ao Supremo só é possível quando houver, antes, a prolação de uma decisão com efeitos vinculantes e erga omnes - ou seja, decisão proferida em controle abstrato de constitucionalidade - não seria possível invocar um eventual descumprimento de decisão do

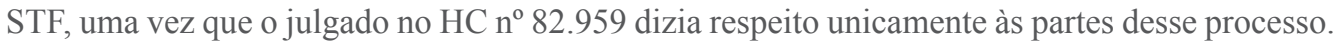

Todavia, o relator, Ministro Gilmar Mendes, desenvolveu argumentação no sentido de que os efeitos da decisão proferida pelo STF em controle concreto deveriam ser os mesmos das decisões proferidas em sede de controle abstrato. Segundo Gilmar Mendes, as reclamações seriam sempre cabíveis quando houver "prejuízo resultante de decisões contrárias às teses do Supremo Tribunal Federal"12. Não haveria, portanto, razão em distinguir-se os efeitos de uma modalidade de controle dos da outra.

Seguindo o voto do relator, o Ministro Eros Grau levou esse entendimento às raias do paroxismo, ao afirmar que "passamos em verdade de um texto [pelo qual] compete privativamente ao Senado Federal suspender a execução, no todo ou em parte, de lei declarada inconstitucional por decisão definitiva do Supremo Tribunal Federal, a outro texto: 'compete privativamente ao Senado Federal dar publicidade à suspensão da execução, operada pelo Supremo Tribunal Federal, de lei declarada inconstitucional, no todo ou em parte, por decisão definitiva do Supremo" "13.

Sobre esse julgado, Lênio Streck manifestou justificável assombro. O STF arrogara-se o direito de "reescrever" o texto constitucional para reduzir o papel do Senado Federal ao de uma "secretaria de divulgação intralegislativa das decisões do Supremo Tribunal Federal". Em outras palavras: retirou-se-lhe o poder de chancelar as decisões do STF, conferindo-lhes efeitos erga omnes e reduziu-se-o a um mero "órgão de imprensa" (STRECK, 2010, p. 5).

Há, no entanto, quem defenda o contrário. Vozes autorizadas na doutrina afirmam que o dispositivo previsto no inciso X do art. 52 da CF/88 “tornou-se um anacronismo" (BARROSO, 2008, p. 130-131). Em respeito ao princípio da economia processual, não faria sentido "obrigar um dos legitimados do art. 103 a propor ação direta para produzir uma decisão que já se sabe qual é!" (BARROSO, 2008, p. 130) ${ }^{14}$.

O fato é que, por essa linha de raciocínio, o inciso X do art. 52 da Constituição Federal de 1988 passaria a vagar como um zumbi, uma norma semiviva. Com efeito, quando se pretende estender ao controle concreto os mesmos efeitos das decisões proferidas em controle abstrato, "cai por terra a própria diferença" entre ambos (STRECK, 2010, p. 5). Desnecessário seria, portanto, cogitar a possibilidade de o Senado estender efeitos que o STF, por si só, já produzira.

12 Trecho do voto do Ministro Gilmar Mendes na Reclamação nº. 4.335/AC.

13 Trecho do voto do Ministro Eros Grau na Reclamação no ${ }^{\circ} .335 /$ AC.

14 Data venia ao ilustre doutrinador, há princípios de maior relevância a ponderar nesse caso, ao lado do princípio da economia processual. Quando a Constituição determina um procedimento específico para declaração de invalidade de normas com ela incompatíveis, este é o rito que deve ser seguido. O modelo pode ser ruim; pode trazer inconvenientes de ordem prática; mas é este o que há. Se é necessário mudá-lo, que se mude. Contudo, a mudança deve respeitar o processo legislativo determinado pelo Poder Constituinte Originário. Se o dispositivo do art. 52, inciso X, da CF/88 tornou-se anacrônico, mude-se a Constituição e equipare-se os efeitos das decisões proferidas em controle concreto às em controle abstrato. Pensar o contrário - ou seja, que o STF, a pretexto de "interpretar" a Constituição possa, de fato, reescrevê-la - significa violar o princípio do devido processo legal, o princípio democrático e o princípio da separação de poderes, todos eles estruturais em um sistema estatal dito "Democrático de Direito". Violá-los em nome tão somente do princípio da economia processual significa injustificável inversão de valores. 
Conhecidas ações “inconhecíveis”, admitida a possibilidade de legislar-de maneira excepcional e transitória - e, finalmente, alterando-se o sentido literal de dispositivo constitucional para estender os efeitos de suas decisões no controle incidental, restava apenas saltar o maior dos muros: reescrever, literalmente, o próprio texto constitucional.

\subsection{A reescrita da Constituição}

E foi justamente isso que aconteceu no julgamento conjunto da Adin n ${ }^{\circ} 4.277 / \mathrm{DF}$, proposta pelo Procurador-geral da República, e da Arguição de Descumprimento de Preceito Fundamental $n^{\circ} 132 / \mathrm{DF}$, ajuizada pelo Governador do Estado do Rio de Janeiro ${ }^{15}$.

Em ambos os casos, defendia-se a possibilidade jurídica de reconhecimento da união estável entre pessoas do mesmo sexo (a chamada "união homoafetiva"). No caso da Adin, o fundamento do pedido era a suposta inconstitucionalidade existente na interpretação conferida ao art. 1.723 do Código Civil, a reconhecer "como entidade familiar a união estável entre o homem e a mulher". No caso da ADPF, o pedido era o mesmo: a utilização da técnica da interpretação conforme para afastar dos incisos II e V do art. 19 e do art. 33, ambos do Decreto-Lei n 220/1975 (Estatuto dos Servidores Públicos Civis do Estado do Rio de Janeiro) - cuja redação é semelhante -, "qualquer intelecção desfavorecedora da convivência estável de servidores homoafetivos, em comparação com a tutela juridicamente conferida à união igualmente estável de servidores heterossexuais".

A questão, contudo, não se resumia à análise da legislação infraconstitucional, seja federal (no caso do Código Civil) ou estadual (no caso do Estatuto dos Servidores do RJ). Ambas as normas apenas reproduziam a dicção do $\S 3^{\circ}$ do art. 226 da Constituição Federal de 1988, segundo o qual "para efeito da proteção do Estado, é reconhecida a união estável entre o homem e a mulher como entidade familiar, devendo a lei facilitar a sua conversão em casamento".

À luz do texto constitucional, portanto, a menção expressa somente à união entre "o homem e a mulher" implicaria a contrario sensu a negativa de proteção do Estado à união entre pessoas do mesmo sexo. Na verdade, o constituinte sequer deixou espaço de manobra para o legislador ordinário (RODRIGUES, 2011, p. 273). A menos que se quisesse entender os vocábulos "homem" e "mulher" como conceitos abertos a serem "preenchidos" pelo intérprete, tem-se aí um evidente caso de "silêncio eloquente do constituinte" "16. Nem mesmo por meio de legislação infraconstitucional seria possível operar a equiparação pretendida (RODRIGUES, 2011, p. 273).

Em malabar esforço argumentativo, o relator, Ministro Ayres Britto, construiu uma engenhosa tese. Segundo ele, quando a Constituição de 1988 fala na indistinção e na isonomia entre os sexos, não estaria a "emprestar a ela o nítido significado de conformação anátomo-fisiológica descoincidente entre o homem e a mulher", mas, sim, "de um laborar normativo no sítio da mais elementar diferenciação entre as duas espécies do gênero humano: a masculina e a feminina".

Melhor explicando: a referência constitucional a "homem e mulher" na verdade seria uma alusão a polos de uma relação amorosa (que estão presentes, est modus in rebus, mesmo em uma relação homossexual). Portanto, desse "silêncio normativo" quanto às demais formas de relacionamento intersexual, inferir-se-ia que, "seja qual for a preferência sexual das pessoas, a qualificação dessa preferência como conduta juridicamente lícita se dá por antecipação"17.

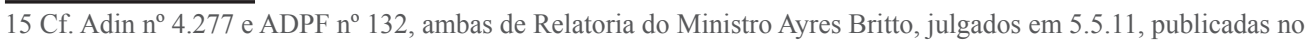
DJU de 16.5.11.

16 Como fez alusão o Ministro Marco Aurélio Mello em seu voto na referida Adin $n^{\circ} 4.277 / \mathrm{DF}$, assim como o Ministro

Ricardo Lewandowski, embora vencido neste particular.

17 Os trechos citados são do voto do Ministro Ayres Britto na Adin nº 4.277/DF. 
Com base nesse voto, o STF julgou procedente o pedido para "dar ao art. 1.723 do Código Civil interpretação conforme à Constituição para dele excluir qualquer significado que impeça o reconhecimento da união contínua, pública e duradoura entre pessoas do mesmo sexo como 'entidade familiar', entendida esta como sinônimo perfeito de 'família'. Reconhecimento que é de ser feito segundo as mesmas regras e com as mesmas consequências da união estável heteroafetiva"18.

E assim, como um passe de mágica, a Constituição Federal foi reescrita pelo Supremo Tribunal Federal ${ }^{19}$. Valendo-se de uma contingência social decorrente da paralisia do legislativo - que se absteve de modificar a Carta Constitucional para tal fim, mesmo já havendo proposta nesse sentido ${ }^{20}$ - o STF valeu-se da tópica para consumar o desejo manifesto de não aceitar ser apenas "um simples aparelho de declaração da validade/nulidade da norma", mas antes um poder "que participa - positiva e negativamente - na própria legislação" (BRITO, 2004, p. 252) ${ }^{21}$.

Esse foi, talvez, o ápice do processo de concentração de poderes da Suprema Corte brasileira - pelo menos até o momento. Tendência, aliás, que já fora denunciada pelo Prof. Otavio Luiz Rodrigues Jr. Segundo ele, vale-se o STF ora de "valores", ora de "princípios" para desconstruir "regras de inquestionável univocidade semântica", chegando-se, assim, "ao extremo de se voltar contra a própria Constituição” (RODRIGUES, 2011, p. 284).

\subsection{Judicialização da política $x$ politização da justiça}

Nessa quadra, a assunção de proeminência política por parte do Poder Judiciário suscita vários problemas, como a "legitimação do poder judicial", o "autogoverno das magistraturas", a "responsabilidade dos juízes" (leia-se: responsabilidade política dos juízes) e, consequentemente, a "automovimentação mediática dos agentes do poder judicial" (CANOTILHO, 2010, p. 658).

É verdade que a judicialização da política é fenômeno recente e, à primeira vista, incontornável dentro da nossa realidade constitucional. Mas, como adverte Manoel Gonçalves Ferreira Filho, a judicialização da política "não se faz sem a politicização da justiça" (FERREIRA FILHO, 1994, p. 11).

Com efeito, o juiz não ocupa, dentro da estrutura do Estado brasileiro, uma posição de "representação", porque à sua função não corresponde qualquer "carácter de representatividade", caráter este ordinariamente presente nos demais poderes representativos da soberania estatal (Executivo e Legislativo) (CANOTILHO, 2010, p. 658). De fato, "embora administrem formalmente a justiça 'em nome do povo"” aos juízes não corresponde qualquer dever de exercer "actividades de direcção política" (CANOTILHO, 2010, p. 658). Se por um lado critica-se os defensores de uma maior contenção do poder judicial como "puristas" ou "ingênuos", por outro "supor que o tribunal pode fazer o que as instituições representativas não têm feito" encerra "ingenuidade ainda mais alarmante" (MENDES, 2011, p. 24).

18 Como alerta Maria Benedita Urbano, não há olvidar-se que “a interpretação conforme com a Constituição não há de ser interpretação contra legem" (URBANO, 2010, p. 417).

19 Cumprindo-se, assim, profecia enunciada pelo Prof. Otavio Luiz Rodrigues Jr.: "No Brasil, porém, muitos tribunais ordinários vêm tomando decisões dessa natureza e, muito provavelmente, o Supremo Tribunal Federal, esforçado em técnicas como a interpretação conforme, poderá fazer a equiparação das uniões homossexuais à união estável ou até ao casamento" (RODRIGUES JR., 2011, p. 273).

20 Cf. PEC n ${ }^{\circ} .159 / 2003$.

21 Aliás, tal faceta foi expressamente admitida pelo Ministro Gilmar Mendes em seu voto, no qual anotou não haver "nenhum dúvida de que o Tribunal está dando uma resposta de caráter positivo" à controvérsia. Voto do Ministro Gilmar Mendes na citada Adin no 4.277/DF. 
Todavia, não há como negar que, dentro da atividade de interpretação normativa, há algo de político dentre as escolhas feitas pelo juiz para resolução de determinado caso concreto. A questão, todavia, é indagar se, no espaço de indeterminação normativa deixado em aberto propositadamente pelo constituinte, não seria o caso de entender-se que a atividade de fiscalização de suas ações e omissões deveria ser sempre guiada pelo benefício ao legislador ordinário, sem desprezar as opções legislativas por ele realizadas em favor da substituição de sua vontade pela da Corte Constitucional. Ou, de forma clara: in dubio, pro legislatori (RAMOS, 2010, p. 453-455).

De fato, trata-se de operação de difícil aceitação acreditar "que um órgão jurisdicional pode julgar a omissão e emitir livremente uma norma em mora a partir, por exemplo, de uma disposição programática que não declara direitos sociais subjectivos" (MORAIS, 2010, p. 46). Nessa linha, estaria o Supremo Tribunal Federal autorizado a fazer juízos políticos próprios do legislador democraticamente legitimado quanto à conveniência e oportunidade de distribuição dos orçamentos públicos, algo particularmente difícil de conciliar com os limites da função jurisdicional. Estaria o STF, no limite, votando as leis do povo, sem dispor de mandato popular para tanto ${ }^{22}$. Como recorda Canotilho, os tribunais em geral - aí incluído, obviamente, o STF - "são órgãos constitucionais aos quais é especialmente confiada a função jurisdicional", e essa função é “exercida por juízes”, não por representantes eleitos pelo voto popular (CANOTILHO, 2010, p. 657). É justamente nisso, a propósito, que se reconduz a sua separação dos outros poderes; ele "só pode ser exercido por tribunais, não podendo ser atribuídas funções jurisdicionais a outros órgãos” (CANOTILHO, 2010, p. 657). E se é assim para os demais poderes, o mesmo deve valer na via contrária: o Judiciário não pode praticar atos outorgados ao Poder Legislativo ou ao Poder Executivo, sob pena de inverter de ponta a cabeça a pirâmide estrutural do Estado brasileiro ${ }^{23}$.

\section{Conclusão}

Como se viu, a questão do ativismo não se resume somente à discussão sobre a judicialização da política, mas à forma através da qual essa maior atividade do STF deve inserir-se na estrutura do Estado Brasileiro. Diretamente, formulando políticas públicas e atuando com verdadeiro "legislador positivo" 24 , ou de outro modo, menos radical e mais consentâneo com a forma de Estado imaginada pelo constituinte de $1988^{25}$. Mesmo temperada com restrições ${ }^{26}$, a atuação legiferante do Supremo Tribunal Federal é algo de difícil compatibilização com o atual texto constitucional.

Em verdade, se o constituinte pensara no STF como guardião da Carta de 1988, enganou-se. Em seu lugar, assumiu uma nova esfera de poder, à margem do Poder Judiciário. Quase 200 anos depois, voltamos à Constituição de 1824. Ao lado dos três poderes tradicionais,

22 Como adverte Mauro Cappelletti, a ideia de tripartição funcional guia o entendimento da "incompetência institucional da magistratura para agir como força criadora do direito" (CAPPELLETTI, 1999, p. 86).

23 Com efeito, "as implicações de certas ênfases no papel messiânico do tribunal constitucional" têm resultado no mais das vezes em "uma cultura jurídica centrada nas cortes judiciais e excessivamente apegada ao "guardião da Constituição", empobrecendo "a experiência democrática" (MENDES, 2011, p. 23).

24 Como defende, por exemplo, Eduardo Ribeiro Moreira.

25 Como defende, por exemplo, Conrado Hübner Mendes.

26 Dirley da Cunha Jr., por exemplo, propõe como limites à atuação normativa do Supremo Tribunal Federal a exclusão de matérias que tratassem de "projetos de códigos e projetos de leis restritivas de direitos, como as definidoras de condutas delituosas e imposições tributárias" (CUNHA JR., 2008, p. 233). Na mesma linha seriam impeditivas decisões que viessem a tratar de "projetos de leis de princípio institutivo, como aqueles que dispõem sobre certas organizações (Conselho da República ou de Defesa Nacional, Advocacia-Geral da União, por exemplo)"(CUNHA JR., 2008, p. 233). 
tem-se agora mais um: o Poder Moderador ${ }^{27}$.

\section{REFERÊNCIAS}

AGRA, Walber de Moura. In MIRANDA, Jorge. Comentários à Constituição Federal de 1988. Rio de Janeiro: Forense, 2009.

BARCELLOS, Ana Paula de. Alguns parâmetros normativos para a ponderação constitucional. In BARROSO, Luís Roberto. A nova interpretação constitucional. 3. ed. São Paulo: Renovar, 2008.

BARROSO, Luís Roberto. Fundamentos teóricos e filosóficos do novo direito constitucional brasileiro (pós-modernidade, teoria crítica e pós-positivismo). In BARROSO, Luís Roberto. A nova interpretação constitucional: ponderação, direitos fundamentais e relações privadas. 3. ed. São Paulo: Renovar, 2008.

BASTOS, Celso. Curso de direito constitucional. 22. ed. São Paulo: Malheiros, 2010.

BRITO, Wladimir. O poder judicial. Boletim da Faculdade de Direito da Universidade de Coimbra, v. LXXX. p. 231-270. Coimbra: Coimbra Editora, 2004.

CANOTILHO, José Joaquim Gomes. Direito Constitucional e Teoria da Constituição. 7. ed. Coimbra: Almedina, 2010.

CAPPELLETTI, Mauro. Juízes legisladores? Trad. Carlos Alberto Álvaro de Oliveira. Porto Alegre: Sérgio Antônio Fabris, 1999.

CUNHA JR., Dirley. Controle de constitucionalidade - Teoria e prática. 3. ed. Salvador: Juspodivm, 2008, p. 41.

FALCONE, Marconi. Justiça constitucional - O caráter jurídico político das decisões do STF. São Paulo: Método, 2008.

FERREIRA FILHO, Manoel Gonçalves. Poder Judiciário na Constituição de 1988. Revista de Direito Administrativo, v. 198. 1-17, out/dez 1994.

FERREIRA FILHO, Manoel Gonçalves. O paradoxo da justiça constitucional. Revista da Faculdade de Direito da Universidade de Lisboa, v. LI, n. 1, p. 17-24. Coimbra: Coimbra Editora, 2010.

MARCATO, Antônio Carlos. Procedimentos Especiais. 12. ed. São Paulo: Atlas, 2006.

MENDES, Conrado Hübner. Direitos fundamentais, separação de poderes e deliberação. 2. ed. São Paulo: Saraiva, 2011.

MENDES, Gilmar Ferreira. Controle abstrato de constitucionalidade: ADI, ADC e ADO. Comentários à Lei no 9.868/99. São Paulo: Saraiva, 2012.

27 O poder moderador estava previsto na Constituição Imperial em seu art. 98, a dispor que tal poder "seria a chave de toda a organização política" e seria "delegado privativamente ao Imperador", de modo que este velasse "incessantemente" pela "manutenção da Independência, equilíbrio e harmonia dos demais poderes políticos". Por intermédio dele, o Imperador pairava sobre o Executivo, o Legislativo e o Judiciário, distorcendo por completo o esquema de tripartição funcional de poderes, haja vista conferir ao monarca poderes quase autocráticos. Não havia, pois, uma real limitação de poder, fundamento último de qualquer ordenamento constitucional (SILVA, 2008, p.

76). Registre-se que o primeiro a imaginar o Poder Moderador como força de contraposição aos demais poderes foi Benjamin Constant (FERREIRA FILHO, 2010. p. 21). 
MOREIRA, Eduardo Ribeiro. Neoconstitucionalismo - a invasão da Constituição. São Paulo: Método, 2008.

MORAIS, Carlos Blanco de. Justiça constitucional. 2. ed. Coimbra: Coimbra Editora, 2011, t. 2. MORAIS, Carlos Blanco de. O controlo de inconstitucionalidade por omissão no ordenamento brasileiro e a tutela dos direitos sociais: um mero ciclo activista ou uma evolução para o paradigma neoconstitucionalista? Lisboa: [Inédito], 2010.

RAMOS, Elival da Silva. Ativismo judicial: parâmetros dogmáticos. São Paulo: Saraiva, 2010. va, 2010 .

Controle de constitucionalidade no Brasil: perspectivas e evolução. São Paulo: Sarai-

RODRIGUES JR., Otavio Luiz. Estatuto epistemológico do Direito Civil contemporâneo na tradição de civil law em face do neoconstitucionalismo e dos princípios. Revista O Direito, $\mathrm{n}^{\mathrm{o}} 143$, p. 267-290, 2011.

SILVA, José Afonso da. Comentário contextual à Constituição. 6. ed. São Paulo: Malheiros, 2009.

. Curso de direito constitucional positivo. 32. ed. São Paulo: Malheiros, 2008.

STRECK, Lênio Luiz; OLIVEIRA, Marcelo Andrade Cattoni e LIMA, Martônio

Mont'alverne Barreto. A nova perspectiva do Supremo Tribunal Federal sobre o controle difuso: Mutação constitucional e limites da legitimidade da jurisdição constitucional. Disponível em: <http://www.mundojuridico.adv.br/sis_artigos/artigos.asp?codigo=912> Acesso em: 19 maio 2010.

TAVARES, André Ramos. Tratado da arguição de descumprimento de preceito fundamental. São Paulo: Saraiva, 2001.

URBANO, Maria Benedita. Interpretação conforme com a constituição e activismo judicial. Revista da Faculdade de Direito da Universidade do Porto. Ano 7, p. 411-418. Coimbra: Coimbra Editora, 2010.

VELlOSO, Carlos Mário da Silva. Le Contrôle de Constitucionalité. In MAUS, Didier; BON, Pierre. La Nouvelle République Brésilienne. Paris: Economica, 1991.

VIANA, Luiz Werneck. A judicialização da política no Brasil. In AA. VV. A judicialização da política e das relações sociais no Brasil. Rio de Janeiro: Revan, 1999.

\title{
JUDICIAL ACTIVISM - CURRENT SCENARIO IN BRAZILIAN FEDERAL SUPREME COURT
}

\begin{abstract}
The judicial activism has emerged, increasingly, as a trend of the Brazilian judicial system. The invasion of the spheres of competence of the Legislature by the Judiciary found fertile ground in the Brazilian Federal Supreme Court. In this article, we will analyze how activism has come to dominate the agenda of the Brazilian Federal Supreme Court, as well as its implications for the legal and constitutional landscape of the country.
\end{abstract}

Keywords: Constitutional Law. Judicial Activism. Neoconstitucionalism.

Data de recebimento: out/2013 - Data de aprovação: mar/2014 
